\begin{tabular}{llllllll}
\hline $\mathrm{A}$ & $\mathrm{R}$ & $\mathrm{T}$ & $\mathrm{Y}$ & $\mathrm{K}$ & $\mathrm{U}$ & Ł & $\mathrm{Y}$
\end{tabular}

\author{
ANNA POMIERNY-WĄSIŃSKA
}

Instytut Historii Polskiej Akademii Nauk

\title{
ZBYTEK ZAREJESTROWANY. \\ O FLORENCKICH SPISACH KOSZTOWNYCH UBIORÓW I OZDÓB Z LAT 1343-1345
}

Zarys treści: Artykuł omawia edycję rejestrów dóbr luksusowych sporządzonych we Florencji w latach 1343-1345. Szczególną uwage przywiązano do scharakteryzowania, na potrzeby polskiego czytelnika, unikatowości tego źródła i jego znaczenia dla badań społecznych (m.in. prozopograficznych) oraz dla szeroko pojętych studiów nad kulturą materialną w miastach późnośredniowiecznych. W drugiej kolejności omówiono wykorzystanie tego źródła $\mathrm{w}$ dotychczasowych badaniach nad ustawodawstwem antyzbytkowym w mieście włoskim oraz przeanalizowano artykuły towarzyszące edycji, które stanowią najnowsze opracowania tej problematyki dla Florencji i bez wattpienia wejdą do kanonu włoskich opracowań dotyczących historii kultury materialnej późnośredniowiecznego miasta.

The content outline: The article discusses registers of luxury gods issued in Florence in 1343-1345. Special care is given to characterise - for the Polish readers - the uniqueness of this source and its importance for social research (i.a. prosopography) and for broadly understood studies on material culture in late medieval towns and cities. Next, the use of this source for research into sumptuary laws in an Italian city is presented, together with an analysis of the articles published with the edition, which are the most recent studies in this area for Florence and will surely enter the canon of standard Italian works in the study of history of material culture of the late medieval Italian city.

Słowa kluczowe: ustawodawstwo antyzbytkowe, późnośredniowieczna Florencja, egzekucja prawa miejskiego, dobra luksusowe, źródła notarialne, historia ubioru

Keywords: sumptuary laws, late medieval Florence, enforcement of municipal law, luxury goods, notarial sources, history of clothes 
W końcu 2013 r., nakładem florenckiego wydawnictwa SISMEL, ukazało się źródło z wielu względów niezwykłe - rejestry dóbr luksusowych sporządzone we Florencji w okresie od jesieni 1343 do wiosny $1345 \mathrm{r}^{1}{ }^{1} \mathrm{~W}$ niniejszym artykule edycja ta zostanie przedstawiona polskiemu czytelnikowi. Moim celem jest wskazanie cech, które świadcza o unikatowości tego źródła i jego znaczeniu dla badań, nie tylko dotyczących walki ze zbytkiem, ale także społecznych, w tym prozopograficznych, oraz dla szeroko pojętych studiów nad kulturą materialna w miastach późnośredniowiecznych. Wskażę zatem perspektywy badawcze, które otwiera lektura owych rejestrów. W drugiej kolejności zajmę się kwestia wykorzystania tego źródła w dotychczasowych badaniach nad ustawodawstwem antyzbytkowym w mieście włoskim oraz omówieniem artykułów towarzyszących edycji, które stanowią najnowsze opracowania tej problematyki dla Florencji. Polskiemu czytelnikowi wyjątkowość omawianego tu źródła może się wydać niemal egzotyczna ${ }^{2}$ - nawet w bogatych archiwach włoskich stanowi ono ewenement, dla którego nie sposób znaleźć porównania. Możliwości badawcze oraz światło, które rzuca na perspektywę badań nad kultura materialna, kultura luksusu i modą oraz elitami społecznymi i ich sposobami autoidentyfikacji, są jednak na tyle znaczące, że warto je tutaj przybliżyć także badaczom z Europy Środkowo-Wschodniej. Także z czysto praktycznego powodu - rejestry moga stanowić jedno z najlepszych źródeł przy badaniach komparatystycznych związanych z historią ubioru, porównaniach ikonograficznych czy poszukiwaniach właściwej terminologii, nawet $\mathrm{w}$ odniesieniu do regionów dalekich od późnośredniowiecznej Florencji. Podczas lektury rejestrów należy jednak pamiętać, że należą one do nielicznych w swoim charakterze, zachowanych dowodów egzekucji ustawodawstwa antyzbytkowego. Sytuacja ta zmieniła się dopiero w epoce nowożytnej, z której to zachowały się liczne źródła pozwalające na ocenę skuteczności leges sumptuariae (np. w kręgu miast hanzeatyckich $)^{3}$.

${ }^{1}$ Draghi rossi e querce azzurre. Elenchi descrittivi di abiti di lusso (Firenze 1343-1345), wyd. L. Gérard-Marchant, Firenze 2013 (Memoria Scripturarum, 6; Testi latini, 4), s. $684+155$, indeks osobowy, słownik terminów.

${ }^{2}$ Problematykę ustawodawstwa antyzbytkowego na ziemiach średniowiecznej Polski jako ostatnio podją Grzegorz Myśliwski, zob. tenże, Leges sumptuariae w średniowiecznym Lwowie, w: Świat średniowiecza. Studia ofiarowane Profesorowi Henrykowi Samsonowiczowi, red. A. Bartoszewicz, G. Myśliwski, J. Pysiak, P. Żmudzki, Warszawa 2007, s. 222-232, tamże literatura przedmiotu.

${ }^{3}$ W literaturze polskojęzycznej zob. prace Edmunda Kizika: Ubiory żałobne w mieście hanzeatyckim w XVI-XVIII wieku, KHKM, t. 44, 1996, nr 2, s. 107-136; Wesele, kilka chrztów i pogrzebów. Uroczystości rodzinne w mieście hanzeatyckim $w$ XVI-XVIII 
Historycy średniowiecza, w tym wypadku północnych Włoch, zwykle dysponuja mniej lub bardziej kompletnym korpusem praw określajacych zakazy (i zasady) korzystania z kosztownych dóbr przez obywateli miejskich, niewiele zaś wiadomo o funkcjonowaniu tego ustawodawstwa $^{4}$. Stan zachowania bazy źródłowej powoduje przesadna autonomizację tekstów o charakterze normatywnym. Warto podkreślić zatem z cała moca, że w przypadku omawianego źródła mamy do czynienia z sytuacja odwrotna od typowej, czyli źródłem potwierdzającym egzekucję praw antyzbytkowych.

Rejestry te sa bez watpienia najbogatszym z zachowanych „inwentarzy" ubiorów i ozdób z okresu późnego średniowiecza ${ }^{5}$. Opisano w nich 6974 części garderoby i 270 ozdób należących do około 2460 osób (w ogromnej większości kobiet). Źródło to, co warto podkreślić, było dotychczas badane $\mathrm{w}$ niewielkim stopniu - choć zostało dostrzeżone przez historyków w pierwszej połowie XX w., korzystano z niego rzadko ${ }^{6}$. Po 1966 r., kiedy florenckie archiwalia, przechowywane wówczas w gmachu dawnych Uffizi, ucierpiały w wyniku wielkiej powodzi, kodeks nie był udostępniany badaczom w normalnym trybie. Przez wzgląd na unikatowość źródła zadecydowano o jego edycji, przygotowanej na podstawie transkrypcji wykonanej jeszcze w latach 80. ubiegłego wieku przez Laurence Gérard-Marchant, kiedy kodeks był jeszcze czytelny w 95\%. Od tego czasu został dwukrotnie poddany konserwacji (ostatnia w 1997 r.), nadal wszakże jest w stanie uniemożliwiającym lekturę nawet przy użyciu lampy ultrafioletowej (lampy Wooda), edycji dokonano więc na podstawie wykonanej wcześniej transkrypcji, wiedząc, że kolejna nie będzie już możliwa?

wieku, Gdańsk 2001; Ubiory mieszczek gdańskich mieszczek w końcu XVI i w pierwszej połowie XVII wieku, „Rocznik Gdański” 67-68, 2007-2008 [2010], s. 17-31.

${ }^{4}$ Zob. m.in. C. Kovesi Practical Problems in the Enforcement of Italian Sumptuary Law, 1200-1500, w: Crime and Disorder in Renaissance Italy, red. K. Lowe, Cambridge 1993, s. 99-120; dla późniejszego okresu zob. J. Bridgeman, „Pagare le pompe”. Why Quattrocento Sumptuary Laws Did Not Work, w: Women in Italian Renaissance Culture and Society, red. L. Panizza, Oxford 2000, s. 209-221.

${ }^{5}$ Kolejny, pochodzacy z 1401 r. z Bolonii, zawiera zaledwie 211 opisów garderoby, zob. M.G. Muzzarelli, Belle vesti, dure leggi: „In hoc libro [...] continentur et descripte sunt omnes et singule vestes", Bologna 2003.

${ }^{6}$ Pierwsze opracowania, których autorzy powoływali się na ten kodeks, to: G. Biagi, The Private Life of the Renaissance Florentines, Firenze 1896; P. D'Ancona, Le vesti delle donne fiorentine nel secolo XIV, Perugia 1906; E. Rodocanachi, Le femme italienne à l'époque de la Renaissance. Sa vie privée et mondaine, son influence sociale, Paris 1907.

7 Także ze względu na stan zachowania kodeksu nie zdecydowano się na wykonanie fotografii ilustrujacych wydanie źródłowe. 
Tytuł wydania - w tłumaczeniu Czerwone smoki i dęby błękitne. Spisy ubiorów luksusowych (Florencja 1343-1345) - stanowi próbę odejścia od nazwy kodeksu stosowanej w literaturze przedmiotu: Prammatica fiorentina/Prammatica sulle vesti. Terminu prammatica, pochodnego od zaczerpniętej z prawa rzymskiego (Justyniana) pragmatica sanctio, przyjęło się używać przede wszystkim na określenie zbioru praw i rozporządzeń (królewskich, cesarskich) w konkretnej dziedzinie, natomiast od XVIII w. stosowano je w Toskanii w odniesieniu do dokumentacji zwiazanej z legislacją i działaniami antyzbytkowymi. Pomimo świadomości o mylącym znaczeniu tego sformułowania w stosunku do treści kodeksu, w części zawierającej edycję źródła zdecydowano o pozostaniu przy jego tradycyjnej, niefortunnie przyjętej nazwie ${ }^{8}-$ La Prammatica sulle vesti delle donne fiorentine. Jest to o tyle mylące, że źródło to nie ma charakteru normatywnego, sa to spisy właścicieli (głównie właścicielek) wraz z rejestrowanymi przez nich i opisanymi (tak by można je było rozpoznać) ubiorami i ozdobami. Podajmy tutaj dla przykładu jeden $\mathrm{z}$ bardziej rozbudowanych opisów:

Domina Angniola uxor Talani de Moççiis populi S. Niccholaii habet guarnacchiam drappi relevati cum campo giallo cum padiglionibus, leonibus, velturis, draghis, leporibus cum bracchis et manus cum fiorettis et avibus, calderugiis, rosais, rosis, capitibus leonis et litteris albis, giallis, nigris et viridibus et vermiliis cum fodera drappi taffeta schachati cum campo sanguingnio. Item habet mantellum drappi chamucha cum campo albo cum panpanis et uvis vermiliis foderatum de drappo sargiato vergato cum campo viridide cum virghis giallis, albis et vermiliis ${ }^{9}$.

Jakie były okoliczności spisania florenckich rejestrów kosztowności? We wrześniu 1343 r. we Florencji zmieniły się władze. Po wygnaniu „tyrana” miasta, Waltera de Brienne, tytularnego Księcia Aten (26 VII 1343 r.) oraz obaleniu krótkotrwałych rządów arystokracji (25 IX 1343 r.), u steru znalazła się elita cechów miejskich. Po raz pierwszy w jej skład weszli nie tylko przedstawiciele siedmiu cechów większych, lecz także członkowie cechów mniejszych, którzy uzyskali wpływ na wybór urzędników miejskich. Wielu z nich pochodziło z grupy nowych obywateli miasta, tzw. novi cives, gente nuova - rodzin, które niedawno osiedliły się w mieście i nigdy dotąd nie sprawowały żadnych

${ }^{8}$ G. Biscione, L'Ufficiale delle donne, degli ornamenti e delle vesti. Profilo istituzionale e vicende archivistiche, w: Draghi rossi..., s. LXXXXII; por. Ch. Klapisch-Zuber, I freni al lusso nella Firenze del Trecento, w: tamże, s. XVIII.

9 Prammatica sulle vesti delle donne fiorentine (Firenze 1343-1345), w: tamże, s. $3-516$, nr 1451. 
urzędów. W porozumieniu z częścia starego florenckiego patrycjatu stworzyli oni rządy tzw. popolanów, które miały przetrwać do 1348 r., aż do katastrofy, jaką przyniosła Czarna Śmierćio.

Jeszcze wczesna jesienia 1343 r. nowa ekipa rządząca rozpoczęła reformowanie państwa. Przywrócono wówczas m.in. ustawodawstwo antyzbytkowe, które miał zawiesić podczas swego panowania Walter de Brienne ${ }^{11}$. Prawa dotyczące noszenia kosztownych strojów i ozdób oraz regulacje dotyczące wystawnych ślubów i pogrzebów znalazły się wówczas wśród najważniejszych i najszybciej przedsięwziętych zmian, tuż obok podstawowych dla ustroju reform dotyczacych systemu wyboru urzędników miejskich ${ }^{12}$ i ustaw wymierzonych w miejską arystokrację ${ }^{13}$. Był to ważny ruch polityczny i zarazem „manifest ideowy” - przywrócenie prawa przeciw luksusowi było wymierzone w tych, którzy szybko wzbogacili się podczas rządów „tyrana” i eksponowali swój awans społeczny poprzez pełne przepychu ubiory. Zaostrzone ustawodawstwo antyzbytkowe miało być prawdopodobnie również elementem szeroko zakrojonej akcji ratowania finansów państwa, które w 1343 r. znajdowały się $\mathrm{w}$ głębokim kryzysie za sprawą niedawno poniesionych wielkich wydatków wojennych oraz problemów ze ściaganiem podatków i korupcji. Walka z luksusem i nadmiernymi wydatkami mieszkańców miasta zdawała się być czymś oczywistym - działaniem, które należało podjąć w ramach odnowy politycznej, finansowej i - co nie mniej ważne - obyczajowej miasta. W skład komisji wyznaczonej do opracowania nowych praw weszli przedstawiciele zarówno popolo grasso, czyli elity bankiersko-kupieckiej i „wolnych zawodów” (lekarze i prawnicy), jak i tzw. magnatów, czyli rodzin prawnie i na stałe odsuniętych od władzy, $\mathrm{z}$ reguły mających stare korzenie feudalne. Byli w tej komisji reprezentanci m.in. dwóch prominentnych rodzin - Bardich (magnati) i Strozzich (popolani), należących do zagorzałych przeciwników Księcia ateńskiego.

10 Więcej zob. B. Becker, Florentine Popular Government (1343-1348), „Proceedings of the American Philosophical Society" 106, 1962, nr 4, s. 381-382.

${ }^{11}$ G. Villani, Nuova Cronica, wyd. G. Porta, Parma 1991, XIII, 8: „E per amore di donna rendé gli ornamenti alle donne di Firenzei” [,Z miłości dla kobiety zawiesił ustawodawstwo antyzbytkowe" - tłum. APW]; o lamencie kronikarza nad zmiana obyczajów noszenia się mężczyzn podczas panowania Księcia ateńskiego zob. tamże, XIII, 4.

12 J.M. Najemy, Corporatism and Consensus in Florentine Electoral Politics, 1280-1400, Chapel Hill 1981, s. 130-150.

${ }^{13}$ Chodzi o tzw. ustawodawstwo antymagnackie, ograniczające m.in. prawa polityczne miejskiej arystokracji, które zostało zniesione późnym latem 1343 r. i natychmiast po przejęciu rządów przez popolanów przywrócone; tamże, s. 381-382; M. Becker, Florentine Popular Government..., s. 375-376. 
Znowelizowane ordinamenti zostały złożone $\mathrm{w}$ komunalnym urzędzie skarbowym (Camera del Comune) 3 XI 1343 r. Ich tekst nie zachował się, przetrwały jednak dowody jego późniejszej egzekucji - raporty z kontroli prowadzonych $\mathrm{w}$ mieście, dowody zapłaty wysokich kar za złamanie tych przepisów ${ }^{14}$ oraz spisy zgłoszonych kosztownych strojów i ozdób, których noszenie dopuszczano pod warunkiem ich wcześniejszej rejestracji. W ramach rozpoczętej już jesienią 1343 r. kampanii mieszkańcy miasta mieli obowiązek zgłosić się do powołanych specjalnie komisji, okazać i zarejestrować wskazane w tych regulacjach ubiory. Ponad 2,5 tys. osób, które to uczyniły (ponieważ brak jednego rejestru, prawdopodobnie było ich więcej), wskazuje na to, że ta droga legalizacji luksusowych przedmiotów przeznaczonych do publicznej ekspozycji, by nie rzec manifestacji, odpowiadała nie tylko władzom, ale i mieszczanom. Ci drudzy, sprawiwszy sobie kosztowne stroje w czasach niedawnego zawieszenia ustawodawstwa antyzbytkowego, zyskiwali możliwość dalszego z nich korzystania, rządzący zaś narzędzia kontroli nad niedopuszczalnym w czasie rządów popolo luksusem. Podobne działania były już stosowane przez władze wcześniej: wiemy, że podobna akcję, choć zapewne na znacznie mniejszą skalę, zorganizowano w 1330 r., gdy wprowadzono poprzednią wielką nowelizację miejskich leges sumptuariae $^{15}$. Zarejestrowane przedmioty nosiły znaki florenckiej komuny miejskiej - pieczęć z lilią i krzyżem ${ }^{16}$.

Rejestry tych strojów zachowały się w kodeksie należącym do zespołu Giudice degli apelli e nullità pod sygnaturą 117 w Archiwum Państwowym

${ }^{14} \mathrm{O}$ raportach z tych kontroli w 1343 i 1344 r. zob.: H. Manikowska, Nadzór $i$ represja. Władza i społeczeństwo $w$ późnośredniowiecznej Florencji, Warszawa 1993, s. 25-27; R. Rainey, Sumptuary Legislation in Renaissance Florence, New York 1985, mps rozprawy doktorskiej, Columbia University, s. 291-427; o zapłatach nałożonych kar zob. M. Becker, Florence in Transition, t. 2: The Decline of the Commune, Baltimore-London 1967, s. 105, 228; por. też Ch. Klapisch-Zuber, dz. cyt., s. XVII-XXXVII.

${ }_{15}$ Wnioskuję o tym na podstawie wzmianki G. Villaniego o rejestrowaniu niektórych ubiorów na mocy nowelizacji z 1330 r.: kobiety, które posiadały stroje z charakterystycznego materiału jedwabnego podobnego do dzisiejszego aksamitu, tzw. sciamito, musiały je zarejestrować, ustawy wprowadzające te zasady nie zachowały się, pisze o nich jednak G. Villani, dz. cyt., X, 153: „nulla si potesse vestire di sciamito, e quelle che ll'aveano il dovessono marcare, acciò ch'altra nol potesse fare” [,żadna z kobiet nie mogła nosić sciamito, a te z nich, które już go posiadały, musiały go zarejestrować, by inne nie mogły tego zrobić" - tłum. APW].

$16,[\ldots]$ cum marchate fuerunt marcho plumbeo habente ex utraque parte lilium et mediam crucem secundum formam ordinamentorum communis Florentie"; Prammatica sulle vesti..., s. 3, 166, 288; zob. też preambuły do pozostałych czterech rejestrów na s. $421,447,455,471$. 
we Florencji (Archivio di Stato di Firenze) ${ }^{17}$, który liczy sobie 307 kart. $\mathrm{Na}$ etapie wykonywania transkrypcji źródła, jak już wspomniano, nieczytelne było około 5\% źródła - podczas powodzi najbardziej ucierpiały karty 230-260, w wydaniu na stronach 385-418, wszystkie te passusy zostały zaznaczone przez wydawcę. Od wydawcy pochodzą numery przyporządkowane kolejnym pozycjom osobowym (1-3257), na marginesie, na wysokości zapisek zawierających datę rejestrowania, które w kodeksie rozpoczynały kolejne strony, umieszczono numery kart kodeksu wraz $\mathrm{z}$ adnotacją verso-recto. Zniszczeniu uległa także wcześniejsza numeracja kart, w związku z czym wydawca zmuszony był przyjąc jedynie numerację arabska, współczesną (wykonaną po 1966 r.), nie udało się również ustalić filigranów ${ }^{18}$.

Na kodeks składa się siedem spisów sporządzonych przez czterech notariuszy miejskich w okresie od 29 X 1343 do 8 IV 1345 r. Trzy $\mathrm{z}$ nich zostały spisane $\mathrm{w}$ całości przez trzech różnych notariuszy (I ser Bartolo di ser Bene di ser Bruni da Vespignano, II - ser Giovanni di ser Corso da Rossoio, III - ser Manfredi di Grimaldo Guidotti; tytuł ser oznacza notariusza). Ostatnie cztery (IV-VII), znacznie różniące się od pozostałych i mniej od nich obszerne, sa dziełem tylko jednego notariusza - ser Lotta di Puccio. Pierwsze trzy łączy zbliżony czas powstania (ostatni trymestr 1343 r.: I: 29 X - 29 XI 1343, II: 29 X - 8 XI 1343, III: $29 \mathrm{X}-29 \mathrm{XI} 1343)$ oraz data przekazania do miejskiego „fiskusa” - 15 XII 1343 r. W tej grupie brakuje ostatniego, czwartego rejestru, o którego sporządzeniu i doręczeniu do Camera del Comune wiemy ${ }^{19}$. Znajdowały się w nim prawdopodobnie opisy zarejestrowanych ubiorów należących do mieszkańców niektórych parafii znajdujących się w centrum miasta, zasiedlonych zresztą przez najstarsze i najbogatsze rody ${ }^{20}$. Powyżej przytoczone informacje oraz lektura rejestrów pod kątem analizy parafii, z których pochodzili właściciele ubiorów, pozwalaja stwierdzić, że Florencję podzielono na cztery części. Do każdej przyporządkowano notariusza odpowiedzialnego za redakcję spisu zgłaszających się do niego mieszkańców danego okręgu. Zastosowany podział miasta nie odpowiadał ani staremu podziałowi na sześć dzielnic (sestieri),

${ }^{17} \mathrm{O}$ rejestrach zob. artykuł towarzyszacy wydaniu źródła: F. Sznura, La „Prammatica fiorentina”. Redazione e contenuto, w: Draghi rossi..., s. XXXIX-LXXIV.

${ }_{18}$ O zastosowanych zasadach edytorskich zob. Draghi rossi..., s. CLII-CLV.

${ }_{19}$ Dokument poświadczający doręczenie rejestru przez ser Falcone di ser Giovanni do archiwum miejskiego zob. Archivio di Stato di Firenze, Miscellanea repubblicana, 9 (bez numeracji kart), 15 XII 1343 r., za: G. Biscione, dz. cyt., s. CLII.

${ }^{20}$ Chodzi o parafie: S. Apollinare, S. Cecilia, S. Michele in Orto, S. Pier Scheraggio i S. Romolo; por. F. Sznura, dz. cyt., tab. 1, s. LXXIII. 
ani wprowadzonemu tuż po wygnaniu Księcia ateńskiego porządkowi czterech dzielnic (quartieri) ${ }^{21}$. Liczba wyznaczonych komisji odpowiada nowo przyjętemu porządkowi, jednak ich zasięg topograficzny już nie. Rejestry przedstawiaja zatem Florencję w istotnym momencie zmiany porządku administracyjnego i są ciekawym przykładem tego, w jaki sposób zmiana ta była wprowadzana w życie, wpływając na praktyki funkcjonariuszy miejskich.

Te pierwsze trzy spisy otwiera także tak samo brzmiąca preambuła ${ }^{22}$. Mówi ona o tym, że spisano w nich właścicielki (sic!) zakazanych prawem komuny Florencji ubiorów i nakryć głów, które zostały w opisane i oznaczone znakami komuny. Tak preambuła, jak i podpisy notariuszy pod spisami sa lakoniczne i trudno na ich podstawie o pogłębiona analizę działań urzędników odpowiedzialnych za egzekucję ustawodawstwa antyzbytkowego w 1343 r. Nie tylko nie wiemy, jaka była zależność notariuszy od nowo powołanej magistratury, ale nawet, jak się ta magistratura nazywała ${ }^{23}$. Możemy jedynie wnioskować, że właściciele kosztownych tkanin zgłaszali się (niekiedy nawet kilkakrotnie) do notariuszy, którzy zapisywali ich tożsamość, parafię, z której pochodzili oraz jak najbardziej szczegółowy opis rejestrowanych dóbr. Zapiski prowadzone były pod datą dzienna, dzięki czemu wiemy, że rejestracji dokonywano przez miesiąc codziennie, za wyjątkiem niedzieli i świąt; w dzielnicy Oltrarno (po drugiej stronie rzeki Arno), którą w całości obejmuje rejestr II, rejestracja trwała krócej.

Pozostałe cztery rejestry, spisane przez Lotta di Puccio, sa znacznie mniej obszerne i dotyczą późniejszego okresu (IV: 10 XII 1343 - 3 IX 1344, V: 7 II - 2 IX 1344, VI: 7 IX 1344 - 31 III 1345, VII: 4 IX 1344 - 8 IV $1345^{24}$. Ser Lotto nie należał zatem do grupy notariuszy wyzna-

${ }^{21}$ Tezie tej zaprzecza Vaucher de la Croix w swoim tekście towarzyszącym wydaniu źródła (tenże, Le parole nell'armadio: lessico della moda nella Prammatica sulle vesti delle donne fiorentine, w: Draghi rossi..., s. CIII-CLII), uznając, że cztery komisje odpowiadały czterem nowym dzielnicom miasta. Tutaj jednak przekonuje nas analiza przedstawiona przez F. Sznurę (dz. cyt., s. LII).

${ }^{22}$ „Infrascripte sunt mulieres que habent vestes, capputea, cappelinas et alia similia capputeo prohibita ferri ex forma ordinamentorum communis Florentie, que marchate fuerunt marcho plumbeo habente ex utraque parte medium lilium et mediam crucem secundum formam ordinamentorum communis Florentie"; Prammatica sulle vesti..., s. 3, 166, 288.

${ }^{23}$ F. Sznura, dz. cyt., s. XLIII.

${ }^{24}$ W pierwszym rejestrze zanotowano 1035 „pozycji osobowych”, w drugim 904, w trzecim 816, w czwartym to już tylko 153, w piątym jedynie 25, w szóstym 83, w siódmym 240. W pierwszych trzech rejestrach przy niektórych osobach znajduje się nawet kilkanaście ubiorów, w spisach Lotta przy każdej osobie zarejestrowany jest jeden przedmiot. 
czonych do realizacji akcji przeprowadzonej późną jesienią 1343 r., brał w niej jednak udział jako notariusz urzędników odpowiedzialnych za przygotowanie regulacji. Wiemy też, że był on odpowiedzialny za spisanie praw antyzbytkowych, odgrywał więc w całym tym przedsięwzięciu rolę większą od pozostałych notariuszy ${ }^{25}$. Z zawartości jego rejestrów wynika, że są one zapisem egzekucji jakiegoś innego przepisu prawnego niż regulacje będące podstawą działań jego trzech kolegów. Prowadzone w chronologicznym porządku jeden po drugim spisy IV i VI rejestruja ubrania wierzchnie szczegółowo określone co do typu - haftowane, wyszywane płaszcze i suknie (mantelli et guarnacchiae continentes figuras), materiałów - z jedwabiu (chamucca [= cammuccà], de serico), wreszcie rozmiaru - wagi. Ich właścicielki były mężatkami (domine). Spisy V i VII to kolejno sporządzone rejestry wykonanych ze srebra ozdób głowy (ghirlande e cerchielli) ${ }^{26}$. Z preambuł do nich ${ }^{27}$ dowiadujemy się, że zarejestrowane u Lotta ubiory i biżuteria były ważone przez cystersów z klasztoru San Salvatore w Settimo, braci konwersów, którzy pełnili funkcję poborców. Ta ostatnia wiadomość nie powinna nas dziwić - zakonnicy i tercjarze powoływani byli na funkcjonariuszy komunalnych organów fiskalnych i niekiedy do prac komisji nadzwyczajnych.

W poszukiwaniu właściwego kryterium miary zbytku posłużono się waga przedmiotów w uncjach ${ }^{28}$. Praktyka ta nie znajduje odzwiercie-

${ }_{25}$ Dokumenty potwierdzajace przekazanie kodyfikacji zob. G. Biscione, dz. cyt., s. CI-CII.

${ }^{26}$ Te dwa ostatnie rejestry zostały wydane już wcześniej przez A. Guidottiego: Gli smalti in documenti Fiorentini fra XIV e XV secolo, „Annali della Scuola Normale di Pisa, Classe di Lettere, e Filosofia" 14, 1984, s. 641-688. Edycja ta przeszła dotychczas jako niezauważona przez badaczy. Wspomina o niej jedynie F. Sznura, dz. cyt., s. XLII.

${ }^{27}$ Preambuła do rejestrów nr IV i VI: „Hic est liber continens dominas habentes mantellos et guarnacchias de quocumque camuccha et quocumque alio drappo de sirico continentes figuras, ponderis videlicet mantellos librarum quattuor vel abinde infra et guarnacchias ponderis librarum trium vel infra cum foderaturis, que mercati sunt et ponderati per religiosos viros fratrem Marchum et fratrem Cristofanum de Septimo camerarios palatii populi florentini secundum formam ordinametnorum comunis Florentie"; w rejestrze nr VII brat Marco zostaje zastapiony przez brata Bartolo; preambuła do rejestrów nr IV i VII: „Hic est liber continens dominas habentes ghirlandas sive cerchiellos de argento ponderis septem unciarum vel abinde citra que marcate et pnderate fuerunt per religiosos viros fratrem Marchum et fratrem Cristofanum conversos de Septimo camerarios Camere armorum palatii populi Florentini vel alterum eorum secundum ordinamentorum comunis Florentie", analogicznie do pary rejestrów Vi VII w rejestrze nr VII brat Marco zostaje zastapiony przez brata Bartolo; Prammatica sulle vesti..., s. 421, 447, 455, 471.

${ }^{28}$ O praktyce ważenia materiałów (obok ich mierzenia) zob. Statuti della Repubblica Fiorentina 1322-25, red. G. Pinto, F. Salvestrini, A. Zorzi, Firenze 1999, t. 2, ks. III, rub. 27, s. 179-80: „De puniendo qui vendiderit pannum nisi ad kannam de 
dlenia we wcześniejszych trzech spisach z 1343 r., gdzie przy rejestrowaniu dóbr notariusze, skupiając się na stworzeniu jak najbardziej szczegółowego opisu, zwracali uwagę na typ, rodzaj materiału, kolor i przede wszystkim sposób jego zdobienia (do zagadnień związanych z opisem części garderoby jeszcze powrócę). Możemy zatem założyć, że przeprowadzona z impetem jesienią 1343 r. kampania, której wynikiem było powstanie pierwszych trzech rejestrów, była wstępem do działań w latach następnych. Na pierwszym etapie powstało coś w rodzaju autoryzowanego spisu, będacego podstawą do skuteczniejszego stosowania przyjętego prawa w kolejnych latach, którego elementem było dalsze prowadzenie rejestru, choć już na innych zasadach (z określeniem wartości przedmiotu poprzez podanie jego wagi). Za egzekucję ustawodawstwa antyzbytkowego odpowiedzialny był ufficiale delle donne (urzędnik cudzoziemski, wybierany na pół roku, pierwszy raz w 1330 r.) i jego famiglia, na którą składali się notariusze i pachołkowie (birri), odpowiedzialni również za kontrolowanie ulic miasta w poszukiwaniu łamiących regulacje mieszkańców Florencji ${ }^{29}$. Spisane w latach $1343-1345$ rejestry miały posłużyć mu jako podstawowy, obok regulacji prawnych, punkt odniesienia $\mathrm{w}$ sprawowaniu kontroli nad przestrzeganiem $\mathrm{w}$ mieście zasad stanowionego prawa.

Preambuły wszystkich siedmiu rejestrów wspominają o mulieres lub dominae jako o właścicielkach zakazanych prawem strojów i ozdób. Nie bez powodu motto na pierwszej karcie kodeksu, napisane wszakże inną ręką niż prowadzącego rejestr notariusza, przywołuje przewrotna naturę kobieca, posługując się powtarzanymi od starożytności przez autorów chrześcijańskich retorycznymi chwytami: „Jeśli chcesz określić albo dowiedzieć się, czymże jest kobieta - jest błotem błyszczącym, różą cuchnąca, słodką trucizna" ${ }^{30}$. Rzeczywiście przeważająca większość zarejestrowanych przedmiotów należy do kobiet - te same właścicielki pojawiają się w spisach kilkukrotnie, często też zgłaszają więcej niż jedną

Kalimala”. W ustawodawstwie antyzbytkowym w przypadku biżuterii waga była jedna z częściej stosowanych miar dla określenia granicy między tym co legalne i nielegalne, obok niej posługiwano się także wartościa przedmiotów podaną w złotych florenach (Archivio di Stato di Firenze, Provvisioni Registri, 15, k. 145v-146r, 9 III 1317(8) r.; Statuti della Repubblica Fiorentina 1322-25..., t. 1, ks. V, rub. 13, s. 207) czy też ich wielkością (w rewizji praw komunalnych z lat 1322-1325 zakazano kobietom noszenia ozdobnych koron, których wysokość przekraczała dwa palce; zob. tamże, s. 208), w rejestrach Lotta di Puccio po raz pierwszy posłużono się wspólną miarą przy ocenie wartości strojów i biżuterii.

${ }^{29}$ O urzędzie zob. G. Biscione, dz. cyt., s. LXXV-CII.

${ }^{30}$ „Si vis diffinire vel quid sit femina scire, est nitidum cenum, rosa fetens, dulce venenum"; Prammatica sulle vesti..., s. 3 (tłum. APW). 
część garderoby. Jako posiadacze kosztownych ubiorów pojawiają się również mężczyźni, ich stosunek do liczby kobiet jest jednak niewielki - zaledwie 66 na 2460 osób. To przede wszystkim młodzi kawalerowie, synowie obywateli miasta. Rejestruja głównie tuniki (czasem zdobione, ale nigdy nie więcej niż dwie, trudno ich liczbę i bogactwo porównywać do zgłaszanych przez kobiety), a niekiedy także kaptury i płaszcze ${ }^{31}$. W dwóch z tych przypadków zgłoszono cottę i cottardite - typy tuniki, które cechują się większym dopasowaniem do ciała, najczęściej są bogato zdobione. Proporcja występowania mężczyzn jako właścicieli zabronionych ubiorów w poszczególnych rejestrach jest skrajnie różna - w spisie nr I mężczyźni w ogóle nie się pojawiaja, w drugim zaledwie dwa razy, a pozostałe 66 wpisów odnajdujemy w rejestrze nr III. Trudno o wyjaśnienie tej dysproporcji. Nie wiemy, co dokładnie o męskich ubiorach mówiła nowelizacja z 1343 r. Być może na jej mocy również mężczyźni mieli rejestrować niektóre z posiadanych przez siebie strojów. Odnotowane różnice między rejestrami mogły wynikać np. z praktyki niezgłaszania zakazanych ubiorów przez mężczyzn z pozostałych części miasta, niejasności lub niezrozumienia komunikatu prawnego dotyczącego konieczności rejestracji czy wreszcie niekonsekwencji w jego egzekucji w odniesieniu do mężczyzn. Nie możemy także wykluczyć faktu, iż być może niektórzy z właścicieli postanowili zgłosić swoje stroje ze względu na to, że cechami odpowiadały one tym, które nakazano zarejestrować kobietom. Mogli o tym zadecydować np. za radą tego z notariuszy, w którego rejestrze odnajdujemy znaczącą większość ze wspomnianych przypadków.

Pojawienie się (choć niezmiernie rzadkie) w źródle młodzieńców i rejestrowanych przez nich tunik możemy wiązać także ze zmianą w modzie florenckiej, odnotowaną przez kronikarza Giovanniego Villaniego, która miała zajść właśnie podczas panowania Waltera de Brienne. Lamentował on, że w ciagu niespełna roku młodzi Florentczycy za sprawą złego wpływu obcej (francuskiej) mody mieli zacząć nosić się krótko i obciśle oraz przepasywać drogocennymi, ozdobnymi pasami. Tę skandaliczna w oczach kronikarza ostentację miały podkreślać zwisające do pasa fałdy kapturów i długie do ziemi rękawy ${ }^{32}$. Nie wszystkie elementy

${ }^{31}$ Przy ich imieniu napisano filius i podano tożsamość ojca (dotyczy to znaczacej większości przypadków, ale nie wszystkich). O szczególnie bogatych zdobieniach i haftach na tunikach wspomniano w poniższych opisach: tamże, nr 2064, 2087, 2095, 2103, 2146, 2257, 2334,2336, 2493, 2492, 2542. Nakrycia głowy i płaszcze zgłosiło pięciu młodzieńców (tamże, nr 2026, 2043, 2064, 2314, 2555).

${ }^{32}$ G. Villani, dz. cyt., XIII, 4; por. A. Pomierny, Zbytek i prestiż. Kategoria ubioru $w$ ustawodawstwie antyzbytkowym komunalnej Florencji, w: Habitus facit hominem. 
stroju wymieniane przez Villaniego odnajdujemy w opisach notariuszy (a w zasadzie jednego z nich - ser Manfrediego di Grimaldo Guidottiego, który jest autorem rejestru nr III). W żadnym $\mathrm{z}$ rejestrów nie odnajdujemy kosztownych pasów męskich, które symbolicznie związane z kultura rycerska (przez broń, która była przy nim noszona), szybko stały się jedną z najważniejszych, najbardziej szykownych części garderoby bogatych kupców i handlarzy ${ }^{33}$. W spisach nie odnajdujemy także informacji o tym, jakiej długości były rękawy zgłaszanych tunik i płaszczy oraz rejestrowane kaptury.

Tych kilkadziesiąt przypadków zarejestrowanych ubrań męskich nie może przysłonić jednak tego, że omawiane rejestry z cała moca potwierdzają panujące w literaturze przedmiotu przeświadczenie, iż późnośredniowieczne ustawodawstwo antyzbytkowe dotyczyło przede wszystkim zwyczajów odzieżowych i ostentacji w stroju kobiet ${ }^{34}$. Warto tutaj przypomnieć, że florenckie leges sumptuariae, gdy poświęcone były regulowaniu zbytku w stroju i ozdobie, tytułowano contra ornamenta mulierum, nawet jeśli zakazy dotyczyły również mężczyzn, urząd zaś, którego zadaniem była egzekucja tych praw, nosił tytuł ufficiale delle (lub sopra le) donne. Oczywiście, nie było to jedynie florencka specyfika. W literaturze przedmiotu wielokrotnie powtarzano, że wygląd miał stanowić dla kobiet jedną z niewielu możliwości określenia i potwierdzenia swojego statusu, roli i obecności w społeczeństwie ${ }^{35}$. Rolę kobiecego wizerunku porównywano do „zwierciadła”, które miało odbijać także prestiż

Społeczne funkcje ubioru $w$ średniowieczu i epoce nowożytnej, red. E. Wółkiewicz, M. Saczyńska, M. Pauk, Warszawa 2016, s. 141-161.

${ }^{33}$ Ten element stroju (tuż po ubiorach sięgajacych do połowy uda) był głównym składnikiem stroju męskiego, którego noszenie było regulowane prawem; zob. m.in. Statuti della Repubblica Fiorentina 1322-25..., t. 1, ks. V, 13, s. 207. Regulacje dotyczące pasów obwiązywały zarówno mężczyzn, jak i kobiety; ich skojarzenie ze strojem męskim spowodowało także usilne próby ograniczenia noszenia kosztownych pasów przez kobiety wszystkich stanów; zob. S.M. Stuard, Gilding the Market Luxury and Fashion in Fourteenth Century Italy, Philadelphia 2006, s. 45-55.

${ }^{34}$ Główne opracowania polityki antyzbytkowej miast włoskich dotyczą właśnie badań nad społeczna rolą kobiety i jej wizerunkiem. Należy tu przede wszystkim wymienić prace: M.G. Muzzarelli (Gli inganni delle apparenze. Disciplina di vesti ed ornamenti alla fine del medioevo, Torino 1996; Reconciling the Privilege of Few with the Common Good. Sumptuary Laws in Medieval Early Modern Europe, "Journal of Medieval and Early Modern Studies" 39, 2009, 3, s. 597-617) i D. Owen Hughes (Regulating Women Fashion, w: A History of Women in the West, t. 2: Silences of Middle Ages, red. Ch. Klapisch-Zuber, Cambridge 1995, s. 136-158). Nurt badań nad sytuacja kobiety w społeczeństwie średniowiecznym stał się wiodącym w analizie ustawodawstwa antyzbytkowego (także przez wzgląd na nacisk, jaki w latach 70. i 80. XX w. zaczęto kłaść na historię kobiet) i dał podstawy do badań z dziedziny gender studies.

${ }^{35}$ M.G. Muzzarelli, Gli inganni delle apparenze..., s. 90. 
małżonka i rodziny ${ }^{36}$. Kobiecy strój i aparycja były narzędziem w tej kwestii niezbędnym, ponieważ widocznym i zrozumiałym dla wszystkich $^{37}$. Niedawne badania rynku dóbr konsumpcyjnych miast włoskich w XIV w. z cała moca podkreśliły fakt, że mężczyźni równie intensywnie jak kobiety używali dóbr luksusowych i okazywali swój status społeczny za pomoca drogocennych ozdób, lecz ich praktyki w mniejszym stopniu były regulowane przez prawo antyzbytkowe ${ }^{38}$. Autorka tych badań, Susan Mosher Stuard uznała, że regulacje antyzbytkowe w XIV w. nie opierały się na podziale na grupy społeczne (jak miało to miejsce u schyłku tegoż wieku i w następnym), lecz za główne kryteria przyjmowały właśnie płeć ${ }^{39}$, a w drugiej kolejności wiek i stan (wprowadzano odmienne restrykcje odnośnie do noszenia wystawnego ubioru przez zamężne kobiety, panny i dziewczęta, a także dla dzieci i młodzieży). Przytoczone informacje o występowaniu w rejestrach mężczyzn (i to w przeważającej części młodzieńców) potwierdzają zarówno tę tezę, jak i socjologiczną teorię Thorsteina Veblena określającą mechanizmy konsumpcyjne w społeczeństwie: kobiety, dzieci i młodzież - obłożone społecznym tabu jako część społeczeństwa niepracująca - „próżnowała na pokaz" i dlatego to przede wszystkim w ich odzieżową ostentację były wymierzone ustawy antyzbytkowe ${ }^{40}$.

Omawiane tutaj rejestry są cennym źródłem do badań nad społeczeństwem Florencji w przededniu Czarnej Śmierci. Szczególnie istotne jest tutaj pojawienie się nieporównywalnej do innych źródeł liczby kobiet mieszkajacych we Florencji. Żadne inne źródło tego okresu nie oferuje

${ }^{36}$ Tamże, s. 89; w innym miejscu (taż, Guarderoba medievale. Vesti e società dal XIII al XVI secolo, Bologna 1999, s. 270) badaczka porównuje kobietę do wystawnego manekinu. W innym miejscu pisze także, że źródła normatywne wydawane przez świeckie władze zwracały się w rzeczywistości do mężczyzn, którzy decydowali o zakupywanych dla swoich żon i córek luksusowych dobrach; taż, Gli inganni delle apparenze..., s. 90-91.

${ }^{37}$ M.in. C. Kovesi Killerby, dz. cyt., s. 112.

${ }^{38} \mathrm{O}$ przepychu w ubiorze męskim zob. S.M. Stuard, dz. cyt., zwł. s. 74, 83. Tendencje dotyczące regulowania prawem obyczajów ubierania dzieci i młodzieży rozwiną się w pełni w drugiej połowie XIV w.; zob. I. Taddei, S'habiller selon l'âge. Le lois somptuaires florentines à la fin du Moyen Âge, „Micrologus” 15, 2007, s. 329-351; taż, Fanciulli senza porpore. Le fogge della moda maschile e la condanna del lusso a Firenze fra XIV e XV secolo, w: Uomini, Paessaggi. Storie. Studi di storia medievale per Giovanni Cherubini, t. 2, red. D. Balestraćci i in., Firenze 2012, s. 1071-1088. Taddei nie bierze pod uwagę w swoich rozważaniach wspomnianych tutaj przypadków z kodeksu Giudice degli appelli e nullitá 17.

${ }^{39}$ S.M. Stuard, dz. cyt., s. 56, 83.

40 Th. Veblen, Teoria klasy próżniaczej, tłum. J. Frentzel-Zagórska, Warszawa 2008; por. H. Manikowska, dz. cyt., s. 256. 
tylu szczegółowych informacji na ich temat. Spisy te stanowią swoisty leksykon popularnych w XIV w. imion żeńskich i moga pomóc w badaniach onomastycznych, zresztą o szerszym zakresie, ponieważ kobiety są tu podporządkowane mężczyznom - mężom lub ojcom, także wymienionym z imienia i nazwiska. Dane osobowe uzupełniaja jeszcze informacje o zamieszkiwanej parafii i stanie cywilnym - filia, uxor, domina (w znaczeniu żona lub wdowa; około 60\% zarejestrowanych kobiet było mężatkami lub wdowami) ${ }^{41}$. Porównywalne co do masowości informacji o kobietach moga być dopiero źródła piętnastowieczne - słynne rejestry kadastralne z 1427 r., w których znalazły się wdowy samodzielnie zarządzające swym majątkiem, oraz zespół Monte delle doti, czyli fundusz posagowy ustanowiony w $1425 \mathrm{r}$.

Spisy mogą być źródłem szczególnie pomocnym w badaniach nad miejską elitą i korzystaniem przez nią z dóbr luksusowych ${ }^{42}$. Na ich kartach pojawiło się około 3\% populacji Florencji, która w połowie lat 40. XIV w. liczyła około 80 tys. osób (a należy tu jeszcze raz podkreślić - to prawie wyłącznie kobiety) ${ }^{43}$. Wśród rodzin, których najwięcej przedstawicielek znalazło się na kartach rejestrów, znajdują się: Strozzi (31), Bardi (30), Adimari (24), Albizzi (24), Altoviti (24) i Acciaiuoli (23). Z nich najwięcej strojów zarejestrowali Adimari (137), Bardi (132), Altoviti (125), Albizzi (119) i Strozzi (106) ${ }^{44}$. Odnajdujemy tu zatem absolutna elitę miasta: rodziny magnackie (Adimari, Bardi) i rody popolo grasso (Acciaiuoli, Albizzi, Altoviti, Strozzi). Część z nich miała prawa polityczne (popolo), pozostała była ich pozbawiona (magnati), wszyscy jednak podlegali regulacjom antyzbytkowym i musieli zarejestrować posiadane kosztowne stroje i biżuterię, o ile chcieli je legalnie nosić. Szlachta nie była spod działania tego ustawodawstwa wyłączona.

${ }^{41}$ Edycji źródła towarzyszy indeks osobowy, który zawiera odniesienia do wszystkich występujących właścicielek i właścicieli rejestrowanych dóbr oraz rodzin, które udało się zidentyfikować. W pozycjach indeksowych zachowano podział na córki i żony (filia, uxor); jako że w rejestrach często pojawiają się formy zdrobniałe imion żeńskich, $\mathrm{w}$ indeksie zadecydowano o zastosowaniu zasady używania podstawowej formy imienia. Jedno z ostatnich opracowań na temat pozycji kobiety w społeczeństwie miejskim Florencji, w tym sposobu określania jej stanu i statusu (choć pozbawione analizy omawianych tutaj rejestrów) to: C. Gros, Images de la femme dans l'historiographie florentine du XIVe siècle, Aix-en-Provence 2009.

${ }^{42}$ Dla późniejszego okresu zob. C.C. Frick, Dressing Renaissance Florence. Families, Fortunes and Fine Clothing, Baltimore-London 2002.

${ }^{43}$ M. Becker, Florentine Popular Government..., s. 368.

${ }_{44}$ Dane na podstawie tabeli przygotowanej przez F. Sznurę, dz. cyt., s. LXXIV; zestawienie 40 najczęściej występujących rodzin zostało stworzone na podstawie przedstawicielek rodów (co najmniej 5); więcej o analizie społecznej rodów znajdujących się na karatach rejestrów zob. tamże, s. LXIII-LXV. 
Obecność obydwu grup w podobnych proporcjach dowodzi także, że trudno tu o wyraźną dystynkcję między popolo grasso a magnatami; różnic należy się doszukiwać przede wszystkim wewnątrz grupy popolo - między jej najbogatszymi rodami a rodzinami mniej zamożnymi lub nowymi w mieście. W rejestrach znaleźć można również rodziny, których przedstawicielki pojawiają się rzadko lub tylko raz, lecz ich stan posiadania jest imponujacco duży, co jest dowodem sukcesu ekonomicznego pojedynczych, często niedawno osiadłych w mieście rodzin ${ }^{45}$.

Największe bogactwo rejestrów stanowią opisy kosztownych strojów i biżuterii. To niezastapione źródło dla historyków ubioru i szerzej, późnośredniowiecznej kultury materialnej, którzy chcieliby zajrzeć do skrzyń bogatych Florentynek i przekonać się, jak ubierano się $\mathrm{w}$ połowie XIV w. oraz co było modne w jednym z najbogatszych miast Europy. Dzięki terminologii użytej w rejestrach wiemy, że za znanymi nam lakonicznymi zakazami zawartymi w prawach antyzbytkowych kryło się niezwykłe bogactwo obrazów i przedstawień namalowanych, wyhaftowanych lub naszytych na stroje. Notariusze odnajdywali na nich m.in.: zwierzęta (zarówno te prawdziwe, jak i mitologiczne) ${ }^{46}$, rośliny ${ }^{47}$, litery ${ }^{48}$, motywy architektoniczne lub krajobrazowe ${ }^{49}$, a także

45 Dla przykładu, pani Gismonda, żona notariusza pochodzącego z Pistoi, mieszkanka parafii S. Maria in Campo, (,domina Gismonda uxor ser Soldi Palestini de Pistoia que moratur in populo S. Marie in Campo"), pojawia się w spisach dwukrotnie - w 1343 i 1345 r., rejestrując razem aż 8 części garderoby; Prammatica sulle vesti..., nr 1017, 2779.

46 Tamże, m.in. nr 58, 59 (motyle, niedźwiedzie, smoki, ptaki), 111 (papugi, smoki, lwy, szczygły), 263 (wilki, psy, motyle), 347 (smoki, lwy, motyle), 748 (syreny, smoki, jelenie), 957 (wiewiórki, psy, motyle, zające, niedźwiedzie), 1451 (lwy, charty, wyżły, smoki, zające, ptaki, kozice), 1712 (smoki, gryfony, lwy, ptaki, wilki), niekiedy w zapiskach widnieje termin animal, bez określenia o przedstawienia jakiego dokładnie zwierzęcia chodzi; zob. tamże, m.in. nr 1949, 2005, 2088, 2254, 2860, 2860. Najbardziej popularne były przedstawienia różnego gatunku ptaków i w drugiej kolejności lwów; więcej przykładów zob. Glossario, w: Draghi rossi..., s. 521-562.

${ }^{47}$ Motywy roślinne często łączą się z tymi zwierzęcymi, to przede wszystkim liście (np. koniczyny), kwiaty i różne gatunki drzew; zob. Prammatica sulle vesti..., m.in. nr 58, 59, 734, 736, 1098, 1102, 1139, 2384. Najczęściej wyszywanym kwiatem były róże (występują w 268 pozycjach rejestru), w drugiej kolejności heraldyczna lilia (zidentyfikowana przez notariuszy miejskich jedynie 58 razy), najpopularniejszymi motywami roślinnymi były te związane z winogronami i winorośla.

${ }^{48}$ Zob. tamże, m.in. nr 77, 269, 329, 481, 625, 639, 651, 1086, 1197, 1208, 1348, 2749, 2758. Przedstawienia liter występuja w rejestrach łącznie 203 razy; por. J.P. Jourdan, La lettre et l'étoffe. Étude sur les lettres dans le dispositif vestimentaire à la fin du Moyen Âge, „Médiévales”, 29, 1995, s. 23-46.

${ }^{49}$ Prammatica sulle vesti..., m.in. nr 390, 1195, 1498, 1693, 175 1935, 2023, (wzgórze); 732, 1269, 1271 (skały); 164, 1032, 1033, 1102, 1269, 1271, 1492, 1943, 
te dekoracyjne, popularne i rozpoznawalne, jak np. węzeł lub splot Salomona (nexus Salomonis, nodus Salomonis) ${ }^{50}$. Rejestry stanowią też niezwykle interesujący materiał do badań związanych z wyobraźnią ikonograficzna, znakami, symbolami i przedstawieniami, które odwołują się do innego świata niż ten związany z rzeczywistością miejską (to świat wsi, ogrodów, podmiejskich wilii i zamków). Na podstawie opisów niemożliwe jest stwierdzenie, w jakich okolicznościach (np. przy okazji jakich uroczystości, w jakim kontekście) stroje z danymi przedstawieniami i wzorami noszono. Otwartym pozostaje pytanie, czy wyobrażenia te wpisywały się w określony kod informacyjny - symboliczny lub emblematyczny - oraz czy odwoływały się do innych tekstów kultury. Odpowiedzi na nie moga dostarczyć jedynie szeroko zakrojone badania, w których omawiane źródło może być potraktowane zaledwie jako pomocnicze.

W opisach najczęściej pojawiających się wyróżników ubioru (materiału) znajdujemy kraty, szachownice i pasy. Te ostatnie na innych przykładach opisał Michel Pastoureau jako wzór niepewny, nieczysty, niemal diabelski, wzbudzający niepokój i mylący wzrok, stwarzający wrażenie dysonansu i bezładu ${ }^{51}$. O ich popularności świadczy ogromna różnorodność terminów użytych w rejestrach do ich opisu (m.in. vergatus, adogatus, divisatus, nastratus). Częstotliwość występowania w ten sposób zdobionych ubiorów jest dowodem rozluźnienia kodów chromatycznych i wzorów geometrycznych, które niosły ze sobą konkretne znaczenia lub budziły określone skojarzenia ${ }^{52}$. Ustawodawstwo antyzbytkowe zakazywało noszenia w ten sposób uszytych lub haftowanych tkanin ${ }^{53}$, jednak

2037, 3048, 2058, 2156, 2264, 2397, 2554, 2588, 2935 (zamki); 1004, 1009, 1012, 1035 (bramy miejskie); mur (2073); 1098 (wieże), 1579, 1954, 1964, 2221, 2295, 2629, 2725 (kolumny), 1252, 1758 (źródła wodne). Ogromnej większości z nich towarzysza przedstawienia gwiazd (występują 364 razy), pojawia się również księżyc i półksiężyc (nr 267, 378,1417, 1493, 1513, 1897, 2145, 2828, 2885) oraz chmury (nr 1130, 1170, 1180, 1271, 1431, 1432, 1434, 1693, 1971, 2515, 2607, 2637, 2939).

50 Tamże, nr 276, 1092, 1146, 1147, 1951, 1960, 1964, 1971, 2115, 2541, 2604, 2652. W słowniku terminów nexus/nodus Salomonis tłumaczony jest jako pentacolo, stella a cinque punte, zob. Glossario..., s. 545; w moim przekonaniu jest to raczej ornament dekoracyjny, znany dobrze z mozaik. Autorka nie podaje źródeł dla swojego rozumienia terminu.

${ }^{51}$ M. Pastoureau, Diabelska materia. Historia pasków i tkanin w paski, tłum. M. Ochab, Warszawa 2004.

${ }^{52}$ Zjawisko to $\mathrm{w}$ polskiej historiografii zdefiniowała ostatnio Anna Adamska w swoim artykule poświęconym kodom chromatycznym i ich percepcji; zob. taż, Gra w kolory, „Roczniki Historyczne” 81, 2015, s. 24.

${ }^{53}$ Giovanni Villani, opisujacc niezachowane regulacje z 1330 r., wskazuje na zakazy dotyczące wszelkiego rodzaju znaków: liter, przedstawień figuralnych, a także pasków, prążków, krat i łączenia wielu kolorów w jednym stroju; tenże, dz. cyt., XI, 151. 
moda i jej mechanizmy (naśladownictwo, snobizm i poszukiwanie ostentacji) doprowadziły do osłabienia tych znaczeń i swoistej ambiwalencji. Lektura opisów pozwala stwierdzić, że notariusze zwracali uwagę przede wszystkim właśnie na fakturę materiałów - sposób ich łączenia ze sobą i wzór, który w jego wyniku powstawał. Niezaprzeczalnie najważniejszą informacja o stroju był dla nich kolor tkanin i wszelkie połączenia chromatyczne - to one pojawiaja się jako najczęściej wykorzystana do scharakteryzowania stroju cecha (nie należy tu zapominać o tym, że barwa i jej intensywność decydowały także o cenie tkaniny).

Dotykamy tu istotnego problemu związanego z charakterem źródła: opisy odzwierciedlają sposób nazywania i charakteryzowania przedmiotów przez notariuszy, na który wpływ mają ich indywidualne kompetencje wizualne. Sposób ten z jednej strony kształtuje język prawa (łacińska terminologia wykorzystana w prawie), z drugiej zaś język praktykowany do opisu ubiorów i zdobień, język wernakularny (w oczywisty sposób znacznie bardziej dynamiczny). Niekiedy mamy do czynienia ze stosowaniem przez pisarzy różnych sformułowań na określenie rzeczy do siebie podobnych (np. przedstawienia roślinne) i trudno o stwierdzenie, czy rzeczywiście odnoszą się one do tych samych, czy też różnych przedstawień. Wymienione przez notariuszy cechy zdobień i wzory sa niczym puzzle, których ułożenie w jedna ikonograficzną całość, bez odniesienia do zabytków kultury materialnej, niestety nigdy nie będzie możliwe (choć moga być bardzo użyteczne przy analizie malarstwa tego okresu). Trudno także o pewność co do tego, kto brał udział w tworzeniu opisu stroju, kto dokonywał klasyfikacji ubioru i wyboru właściwych terminów, wreszcie: w jakim stopniu w tym procesie powstania opisu ubioru brali udział sami jego właściciele ${ }^{54}$. Nie pojawiają się w nim natomiast informacje o długości strojów - kryterium, które w regulacjach jest ważnym sposobem ograniczania zbytku i ostentacji. Przynoszone ubiory były okazywane, ale nie noszone w obecności notariuszy, stąd być może brak odniesień w opisach np. do długości trenów i rękawów w kobiecych sukniach (mierzonych w łokciach florenckich) albo męskich tunik ${ }^{55}$.

${ }^{54} \mathrm{O}$ dyskusjach dot. nazywania ubiorów i ozdób między urzędnikiem odpowiedzialnym za egzekucję prawa i kobietami je noszącymi oraz związanej z tym klasyfikacji pisze 40 lat później Franco Sacchetti w jednej ze swych nowel; zob. tenże, Il Trecentonovelle, red. E. Faccioli, Torino 1979, s. 360 (nov. CXXXVII).

${ }^{55} \mathrm{~W}$ późniejszych prawach, które się zachowały, miara w tym przypadku było ludzkie ciało - zakazane było noszenie ubrań krótszych niż do połowy uda, co oczywiście związane było nie tyle z wystawnością stroju i marnotrawstwem kosztownego materiału (jak w przypadku kobiecych trenów), ile ze skandaliczną ostentacją i niepo- 
Lektura rejestrów daje pewne możliwości uchwycenia zwyczajów dotyczących strojów poszczególnych kobiet (a nawet ich gustów) oraz trendów w modzie. Należało do nich np. stosowanie liter, które nie tylko wskazywały na właścicielkę stroju, lecz także mogły stać się nośnikami szczególnych treści i przynależności do danej grupy lub rodu, jak działo się w przypadku późniejszych już prawdopodobnie monogramów, impres i emblematów.

Edycja przygotowana przez Laurence Gérard-Marchant może otworzyć drogę do rewizji niektórych z przyjętych literaturze przedmiotu poglądów. Jednym z przykładów jest częściowo już dokonana rewizja modelowej i bardzo pociagającej interpretacji kształtowania pozycji w społeczeństwie miejskim i sposobów indywidualnej bądź wspólnotowej identyfikacji za pomocą stroju i jego ozdób: lektura opisów ubiorów doprowadziła do podważenia hipotezy Diane Owen Hughes o rodowej monopolizacji wybranego znaku bądź symbolu w pierwszej połowie XIV stulecia $^{56}$. Wydaje się, że w tym okresie w społeczeństwie miejskim rody arystokratyczne częściej używały koloru jako elementu identyfikacyjnego, odzwierciedlającego znaczenie rodziny, jej liczebność (np. w przypadku uroczystości publicznych, gdy poprzez użycie tego samego koloru rodziny pokazywały, jak licznie uczestnicza w danym wydarzeniu: one i ich stronnicy) i sytuację, która pewnego koloru wymagała (szczególnie żałobę) $)^{57}$. O tym, że podobnie uszyte stroje w tych samych kolorach były noszone przez przedstawicielki tej samej rodziny wiemy m.in. dzięki kobietom (niezamężnym) z rodziny Altovitich, które jako jedne z pierwszych stawiły się, i to razem, w celu zarejestrowania swych strojów pierwszego dnia rejestracji, 29 X 1343 r.:

szanowaniem obyczajów: Archivio di Stato di Firenze, Capitoli del Comune di Firenze, 12, k. 69r, za: R. Rainey, Sumptuary Legislation..., s. 269, przyp. 77. O wpływie stroju na zmianę w postrzeganiu ciała ludzkiego zob. U. Rublack, Dressing Up. Cultural Identity in Renaissance Europe, Oxford 2011, s. 16-17.

${ }^{56}$ Diane Owen Hughes oparła swoją hipotezę na przypadku kobiet z rodziny Albizzich; zob. taż, Sumptuary Laws and Social Relations in Renaissance Italy, w: Disputes and settlements. Laws and Human Relations in the West, red. J. Bossy, Cambridge 1983, s. 87-88, s. 87-88; krytykę tej hipotezy zob. L. Gérard-Marchant, Aspetti della moda femminile a Firenze nella Prammatica del 1343, w: Draghi rossi..., s. XIII; F. Sznura, dz. cyt., s. LXX.

${ }^{57}$ A. Esposito, La società urbana e la morte: le leggi suntuarie, w: La morte e i suoi riti in Italia tra Medioevo e prima età moderna, red. F. Salvestrini, G.M. Varanini, A. Zangarini, Firenze 2007, s. 97-130; A. Pomierny, Zakazana ostentacja. Florenckie prawa antyzbytkowe $z$ pierwszej połowy XIV $w$. o ceremoniach ślubnych i pogrzebowych, Warszawa 2013, mps pracy magisterskiej, IH UW, s. 35-51; por. A. Adamska, dz. cyt., s. 17-34. 
Dingha filia Sandri Altoviti habet unam tunicham dimezzatam per transversum in una parte coloris sanguine schachatti cum virgis de siricho et in alia parte coloris scharlatini mescholati (Prammatica sulle vesti, $\mathrm{nr} 3$ ).

Lisabetta filia Gentilis Altoviti habet unam tunicham dimezzatam per transversum in una parte coloris sanguine schachati cum virgis de siricho et in alia parte coloris scharlattini mescholati (Prammatica sulle vesti, nr 4).

\section{$* * *$}

Warto w tym miejscu poświęcić także nieco uwagi dwóm zagadnieniom: wykorzystaniu i obecności rękopisu w dotychczasowych badaniach nad florenckim ustawodawstwem antyzbytkowym oraz opracowaniom towarzyszacym jego edycji.

Najważniejsze opracowania poświęcone ustawodawstwu antyzbytkowemu Florencji nie zawierają analizy tego źródła, a co najwyżej wspominają o jego istnieniu. Ronald E. Rainey, autor podstawowej, choć niewydanej pracy na ten temat, wiedział o istnieniu tych rejestrów, jednak nie mógł z niego skorzystać $\mathrm{z}$ powodu stanu zachowania rękopisu ${ }^{58}$. Jego praca, ze względu na znikomą dotąd liczbę edycji źródeł prawnych dla tego miasta, jest głównym cytowanym przez badaczy opracowaniem niezastapione były dotychczas obszerne passusy wilkierzy miejskich i rewizji statutów cytowane w aparacie krytycznym pracy i jej dodatkach źródłowych oraz zrekonstruowana chronologia praw ${ }^{59}$. Omawiane tutaj rejestry nie znalazły się również w bazie źródłowej opublikowanego przez niego artykułu, w którym streszcza wyniki swojej rozprawy doktorskiej, znacznie zawężając pole swoich badań do analizy kształtowania wizerunku kobiet za pomoca kosztownych strojów i biżuterii ${ }^{60}$.

Brak odniesień do omawianych tutaj rejestrów w pracach Raineya, traktowanych niemal jak przewodnik archiwalny po florenckich ustawach antyzbytkowych, był zapewne jednym z powodów, dla których

${ }^{58}$ R. Rainey, Sumptuary Legislation..., s. 364, przyp. 12.

${ }^{59} \mathrm{~W}$ listopadzie 2016 r. Archivio di Stato di Firenze udostępniło zdygitalizowane rejestry wilkierzy miejskich Florencji z lat 1285-1530, które umożliwiają samodzielne przeprowadzenie podobnej kwerendy; zob. http://www.archiviodistato.firenze.it/archividigitali/complesso-archivistico/?id=5 (28 III 2017).

${ }^{60}$ R. Rainey, Dressing Down the Dressed-Up. Reproving Feminine Attire in Renaissance Florence, w: Renaissance Society and Culture. Essays in Honour of Eugene F. Rice, red. J. Monfasani, R.G. Musto, New York 1991, s. 217-237. Autor skupia się na analizie regulacji dotyczących kobiecego ubioru i ozdób oraz rozpatrywaniu motywacji władz, uwarunkowań ekonomicznych i rozwijającej się w kaznodziejstwie (w tym przypadku piętnastowiecznym) „etyce antyzbytkowej”. 
do źródła nie dotarła Susan Mosher Stuard ${ }^{61}$, badaczka rynku dóbr luksusowych w miastach włoskich XIV w. W tym przypadku brak ten jest wyjątkowo rażący. Dla Stuard, której celem było badanie przede wszystkim zagadnień związanych z popytem i tezauryzacja, rejestry będące największym zachowanym inwentarzem kosztowności z tego okresu mogły się okazać nieocenionym źródłem, uzupełniającym i być może niekiedy rewidującym wiedzę płynąca z analizy regulacji prawnych wymierzonych w kulturę zbytku i ostentacji. Podobną hipotezę można postawić także w stosunku do pracy Catherine Kovesi Killerby, monografii poświęconej ustawodawstwu miast włoskich z lat 1200-1500, obecnie najłatwiej dostępnego opracowania tej tematyki i jednocześnie najbardziej ogólnego, w którym autorka, opracowując zagadnienia związane $\mathrm{z}$ regulacjami antyzbytkowymi Florencji, oparła się na źródłach zgromadzonych przez Ronalda Raineya ${ }^{62}$.

$\mathrm{Na}$ rejestry zwrócił uwagę Marvin Becker w swoim artykule poświęconym polityce florenckiej w latach 40 . XIV w., analizując ich powstanie $\mathrm{w}$ kontekście reform wprowadzanych w trakcie rządów popolanów ${ }^{63}$. Za sprawą informacji odnalezionej w jego opracowaniu o istnieniu rejestrów napisała krótko Catherine Guimbard, autorka drugiego po pracy Raineya najważniejszego opracowania ustawodawstwa antyzbytkowego w czternastowiecznej Florencji ${ }^{64}$. Jej interpretacja praw wymierzonych $\mathrm{w}$ zbytek i ostentację polega na powiązaniu ich stanowienia z ideologia komunalna - to przede wszystkim analiza posługiwania się narzędziem regulacji antyzbytkowych w konfliktach politycznych. Egzekucji tych praw autorka nie poświęca jednak wiele miejsca, a o omawianych tutaj spisach jedynie wspomina, zwracajacc uwagę na praktykę rejestrowania kosztowności, których noszenie było zakazane litera prawa.

Warto tutaj również odnotować, że historycy, którzy badali sposoby egzekucji ustawodawstwa antyzbytkowego we Florencji, opierali się dotychczas przede wszystkim na zachowanych księgach sądowych z zespołu Esecutore degli Ordinamenti degli Giustizia i źródłach fiskalnych, tj. wpłatach grzywien do skarbca komunalnego (Camarlinghi della Camera del Comune: Entrata ${ }^{65}$. Wyjątek stanowi tu praca Haliny Manikowskiej, która przeprowadzając kwerendę w zespole

${ }^{61}$ S.M. Stuard, dz. cyt.

${ }^{62}$ C. Kovesi Killerby, dz. cyt.

${ }^{63}$ M. Becker, Florentine Popular Government..., s. 381-382.

${ }_{64}$ C. Guimbard, Appunti sulla legislazione suntuaria à Firenze dal 1281 al 1381, „Archivio Storico Italiano” 150, 1992, s. 57-81; o rejestrze zob. s. 64.

${ }_{65}$ Zob. wyżej, przyp. 14; R. Rainey, Sumptuary Legislation..., s. 291-427; o zapłatach zob. M. Becker, Florence in Transition..., s. 105, 228. 
Giudice degli appelli e nullità, dotarła także do tego rękopisu i opisując działania związane z egzekucja ustawodawstwa antyzbytkowego jako egzemplifikację praktyk aparatu kontroli i represji, przedstawiła krótko wnioski z jego lektury ${ }^{66}$. Niestety przez wzgląd na język publikacji wyników pracy wnioski na temat egzekucji ustaw antyzbytkowych nie były dotychczas znane zagranicznym badaczom.

Wiele z tez Manikowskiej pokrywa się z tymi, które w omawianym tomie stawia Christine Klapisch-Zuber, autorka tekstu mającego na celu prezentację rejestrów na tle szerszej problematyki egzekucji florenckich leges suptuariae ${ }^{67}$. Podobnie jak Manikowska, Klapisch-Zuber podkreśla, że konflikty polityczne w mieście, w tym w szczególności ten przebiegajaccy na linii popolo - magnati, nie były jedynymi przyczynami ich stanowienia, a samych praw nie należy rozumieć jedynie jako próbę uderzenia w pozycję miejskiej arystokracji. Choć kolejne fale nowelizacji ustawodawstwa były związane ze zmianami politycznymi, wprowadzane regulacje w dużym stopniu wiązały się również z próbą ratowania miejskich finansów, polityką cechów miejskich oraz próbami odwołania się do ideału skromnego życia mieszczan, który zakładał ograniczenie nadmiernych wydatków na dobra luksusowe i ostentacji. W dużym stopniu były także związane z chęcia pohamowania nadmiernych ambicji ludzi, którzy bogacąc się $\mathrm{w}$ szybkim tempie, za pomocą ostentacji w stroju i jego ozdobie pragnęli zaprezentować swój prestiż, który według starej elity miasta (popolo grasso, magnati) do nich nie przynależał ${ }^{68}$. Nie bez znaczenia było tutaj pojawienie się na wielką skalę w tym czasie nowych obywateli miejskich (nuovi cives, gente nuova). Byli oni grupa heterogeniczna, z ogromnymi aspiracjami do uzyskania wyższego statusu i w wysokim stopniu naśladująca zachowania elity, czym wywołali reakcję starego patrycjatu, który z kolei bronił się, wzmacniając strukturę i kategoryzację hierarchii społecznej. Im bardziej społeczeństwo wykazywało się mobilnością i dynamicznymi zmianami, tym silniej starano się uwydatnić linie przebiegających wewnątrz niego podziałów. Narzędziem do tego przydatnym było właśnie ustawodawstwo antyzbytkowe, czego dowody odnajdujemy przede wszystkim w regulacjach z drugiej połowy XIV w. ${ }^{69}$, które nie są przedmiotem tutejszych rozważań.

Analizując podjętą przez władze w mieście walkę ze zbytkiem w pierwszej połowie XIV w., Klapisch-Zuber charakteryzuje wprowadzane

${ }^{66}$ H. Manikowska, dz. cyt., s. 266.

${ }^{67}$ Ch. Klapisch-Zuber, dz. cyt., s. XVII-XXVIII.

68 Por.: H. Manikowska, dz. cyt., s. 252-253; Ch. Klapisch-Zuber, dz. cyt., s. XXX-XXXII. Obie autorki dystansują się od tez stawianych przez C. Guimbard.

${ }^{69}$ Zob. też A. Pomierny, Zakazana ostentacja..., s. 92. 
regulacje, a szczególną uwagę zwraca przy tym na środki wskazywane do ich egzekucji ${ }^{70}$. Autorka wymienia dwie, niekiedy równolegle stosowane strategie: pierwszą była kontrola prowadzona w mieście w celu wychwycenia przypadków łamania prawa, której towarzyszyło nałożenie kary pieniężnej i konfiskata, druga zaś wszelkie próby licencjonowania i opodatkowywania prawa do zakazanych części garderoby i biżuterii, wśród których istotne były również akcje rejestrowania dóbr ${ }^{71}$. Analizę rozwoju sposobów egzekucji prawa kończy na 1365 r., kiedy wprowadzono stały podatek od luksusu - płacona raz do roku gabelle, której wysokość zależała od kosztowności stroju. Wielka zaleta tekstu Klapisch-Zuber jest nie tyle oryginalność postawionych przez nia tez, ile zwięzłe ich przedstawienie. W dużej mierze wnioski badaczki na temat strategii walki ze zbytkiem pokrywają się z tymi, które czytelnik odkryje we wcześniejszych opracowaniach tej tematyki, przypomnijmy jednak, że najważniejsze z nich, poświęcona Florencji praca Ronalda Raineya, wciąż dostępna jest jedynie w formie niewydanej rozprawy doktorskiej. Artykuł ten stanowi także uzupełnienie rozważań Catherine Guimbard, która skupia się przede wszystkim na analizie tekstów normatywnych i politycznego kontekstu ich spisania, a nie próbach egzekucji.

Zawarte w artykule Klapisch-Zuber uwagi dotyczące walki z przesadnym luksusem i nadmiernymi wydatkami w czternastowiecznej Florencji uzupełnia artykuł Giuseppe Biscione poświęcony urzędowi odpowiedzialnemu za kontrolę $\mathrm{w}$ tej dziedzinie ${ }^{72}$. Jest to tekst paradoksalnie najmniej związany z treścią wydanego kodeksu, jednak istotny przez wzgląd na to, że urząd ufficiale delle donne, degli ordinamenti e delle vesti nie doczekał się dotychczas oddzielnego opracowania. Biscione słusznie zauważa, że badacze częściej zajmują się treścią ustaw antyzbytkowych niż śladami działalności organu, który we Florencji istniał zaledwie kilkanaście lat (do 1345 r.). Później jego kompetencje zostały przekazane innym urzędom: Esecutore degli ordinamenti di giustizia (do 1356 r.) i Giudice degli appelli e nullità (do 1406 r.). Przywołany tekst to przede wszystkim opracowanie zachowanego $\mathrm{w}$ archiwum

${ }^{70}$ Przedstawiając chronologię stanowienia praw, badaczka w znacznym stopniu opiera się na pracy Ronalda Raineya; uzupełnia zgromadzone przez niego źródła o niezauważony przez niego opis praw wydanych w 1345 r., który zachował się w notatkach Scipione Ammirato do jego kroniki dziejów Florencji (Istorie florentine, spisane w XV w.); tekst ten opublikowano w aneksie źródłowym do artykułu; zob. Ch. Klapisch-Zuber, dz. cyt., s. XXXV-IV.

71 Tamże, s. XXVII.

${ }^{72}$ G. Biscione, dz. cyt., s. LXXV-CLII. 
florenckim materiału źródłowego ${ }^{73}$. Autor przedstawił także listę urzędników cudzoziemskich pełniących funkcję ufficiale delle donne w latach 1330-1345, wraz z odniesieniami do dokumentów, które dowodzą ich wyboru na ten urząd oraz liczbą notariuszy i pachołków, którzy wchodzili w skład ich famiglii ${ }^{74}$. Niestety w opracowaniu tym zabrakło próby odpowiedzi na pytanie o to, jak z praca urzędników odpowiedzialnych za egzekucję ustaw antyzbytkowych były związane spisy ubiorów i ozdób głowy z lat 1343-1345. Biscione nie porównał dat powstawania rejestrów z kadencjami ufficiali delle donne i nie zauważył np., że jedynie daty powstania ostatnich dwóch spisów, przygotowanych przez Lotta di Puccio (VI i VII), pokrywają się z jego kadencja ${ }^{75}$. Wobec tej luki trudno o stuprocentowa pewność, czy rejestry były spisywane przez notariuszy z famiglii tych urzędników: prawdopodobnie powstały równolegle, przez specjalnie do tego wyznaczonych funkcjonariuszy.

Autorem głównego i najbardziej szczegółowego opracowania dotyczącego powstania rejestrów jest Franek Sznura ${ }^{76}$. Jako jeden z najbardziej kompetentnych znawców florenckiego notariatu ${ }^{77}$, skupia się on na analizie kodeksu właśnie pod kątem pracy notariuszy. W pierwszej części swojego tekstu przedstawia krótką charakterystykę każdego ze spisów. Na podstawie szczegółowej analizy zawartych w spisach informacji precyzyjnie ustalił on zakres topograficzny działań notariuszy i określił obszar miasta, który w trzech pierwszych i obejmujących najwięcej osób rejestrach nie figuruje (czwarty rejestr, przypomnijmy, się nie zachował). Jeden z ciekawszych fragmentów artykułu Sznury poświęcony jest przypadkowi Florentynki imieniem Taddea, która 30 XII 1345 r. została przyłapana na noszeniu zakazanego prawem stroju. Ze względu na to, że stanowi on dobrą ilustrację tego, w jaki sposób omawiane rejestry wspomagały skuteczny sposób egzekucji ustawodawstwa antyzbytkowego, warto go tutaj przytoczyć

${ }^{73}$ Ufficiale delle donne nie posiada własnego zespołu w Archivio di Stato di Firenze.

${ }^{74}$ Informacje te pochodza przede wszystkim z lektury ksiag zawierajacych informacje o głosowaniach rad miejskich Libri fabarum; zob. Appendice II, w: G. Biscione, dz. cyt., s. XCIX-C.

75 Tamże, s. C, nr 27.

${ }^{76}$ F. Sznura, dz. cyt., s. XXXIX-LXXIV.

77 Tenże, Il notaio nella civiltà fiorentina, secoli XIII-XVI, Firenze 1984; Per la storia del notariato fiorentino: $i$ più antichi elenchi superstiti dei giudici e dei notai fiorentini (anni 1291 e 1338), w: Tra libri e carte. Studi in onore di Luciana Mosiici, red. T. De Robertis, G. Savino, Firenze 1998, s. 437-515. F. Sznura jest również opiekunem serii wydawniczej publikowanej przez SISMEL, w ramach której ukazują się edycje wybranych rejestrów notarialnych z zespołu Notarile Antecosimiano (Archivio di Stato di Firenze). 
za autorem ${ }^{78}$. Przyłapana na goracym uczynku Taddea kilka tygodni później tłumaczyła, że „fecit marchari et marchata fuit et est [guarnacca] secundum formam ordinamentorum comunis Florentie super predictis habitis". Na kartach spisu ser Manfrediego di Grimaldo Guidotti, który zarejestrował posiadane przez nią stroje, widniały jednak opisy, które nie pasowały do tych, na których noszeniu została przyłapana. Obciażono ją zatem karą pieniężna.

W'́ród pytań stawianych przez Sznurę wiele pozostawia on bez odpowiedzi: w jaki sposób i kiedy oznaczano stroje pieczęcią ze znakami komuny? W jaki sposób przynoszono kosztowności do miejsc, w których pracowali notariusze? Skoro przy niektórych właścicielkach widnieje nawet kilkanaście strojów - to czy wszystkie były przynoszone w tym samym momencie? Na podstawie treści rejestrów nie sposób na nie odpowiedzieć. Historyk zwraca również uwagę na problemy z właściwą interpretacją terminu domina, który występuje przy części z właścicielek strojów: można traktować go jako synonim słowa uxor, ale $\mathrm{w}$ ten sposób mogła być tytułowana również wdowa ${ }^{79}$. W końcowej części opracowania autor przedstawia krótką analizę tego, w jaki sposób były zdobione zarejestrowane stroje oraz podstawowe obliczenia statystyczne dotyczące rodzin najczęściej pojawiających się w rejestrach, na które powoływałam się wcześniej ${ }^{80}$.

Edytorka źródła, Laurence Gérard-Marchant, w niniejszym tomie jest autorką jedynie krótkiego wstępu, w którym przedstawia podstawowe informacje dotyczace chronologii wprowadzenia ustaw antyzbytkowych, od pierwszych zachowanych wzmianek (druga połowa XIII w.) po lata 40 . XIV w., na tle przemian politycznych w mieście, które miały wpływ na kolejne stanowione prawa (to interpretacja w dużym stopniu oparta na wspomnianej pracy Raineya). Niestety wśród artykułów towarzyszących wydaniu rejestrów zabrakło tekstu zbierającego informacje przedstawione przez wydawczynię we wcześniejszych jej pracach, poświęconych ubiorom opisanym w rejestrach, w których podawała m.in. częstotliwość występowania poszczególnych części garderoby i ich cech $\mathrm{w}$ formie użytecznych tabel ${ }^{81}$. W opublikowanym tutaj krótkim

${ }^{78}$ Dokumentacja sądowa z zespołu Esecutore degli Ordinamenti di giustizia, na podstawie której opisano tę sytuację, zob. F. Sznura, La „Prammatica fiorentina”..., s. XLVI-XLVII. W omawianych rejestrach domina Taddea uxor Bernardi de Bordonibus populi S. Michelis pojawia się dwukrotnie, pod nr. 1941 i 1963 (29 i 30 X 1343 r.).

79 Tamże, LXI-LXII.

80 Tamże, tab. 2, s. LXXIV.

${ }^{81}$ L. Gérard-Marchant (taż, Aspetti della moda femminile..., s. IX-XVI) jest także autorką dwóch opracowań cząstkowych tego kodeksu, poświęconych refleksji nad 
tekście znalazło się jedynie zestawienie najczęściej występujących kolorów ${ }^{82}$. Zabrakło w nim jednak wniosków dotyczących tego, które z nich najczęściej ze sobą łączono w wielobarwnych strojach - opisy zawarte $\mathrm{w}$ rejestrach mogłyby się okazać interesujące w badaniach nad najpopularniejszymi zestawieniami chromatycznymi oraz ich ewentualnymi źródłami (m.in. malarstwo, symbolika kolorów i ich znaczenie w określonych sytuacjach).

Przygotowany przez Joëla F. Vauchera de la Croix słownik terminów pełni również funkcję indeksu rzeczowego. Przy terminach użytych przez notariuszy przy opisie strojów: ich rodzaju, materiału, zdobienia itd. podano krótkie objaśnienie i numery zapisek, w których występuja. Te ostatnie pominięto $\mathrm{w}$ przypadku terminów, których użycie jest bardzo częste (chodzi tu przede wszystkim o kolory - np. vermilius: intensywnie czerwony, występuje 2440 razy, giallus: źołty, 3282 razy). Objaśnienia sa niekiedy bardzo lakoniczne i pozostawiaja czasem wątpliwości, co dowodzi, że autor słownika po wielokroć miał problemy z ich właściwą identyfikacja, dotyczy to przede wszystkim przedstawień wyhaftowanych na strojach i typów zdobień. Dodatkowym utrudnieniem jest brak informacji o literaturze przedmiotu, na podstawie której tworzony był słownik ${ }^{83}$. Tylko w pewnym stopniu łagodzi go zamieszczony we wstępnej części do edycji szkic leksykologiczny autorstwa tego samego badacza, poświęcony terminologii użytej w inwentarzu oraz etymologii wybranych pojęć i terminów ${ }^{84}$. Zgromadzone i wytłumaczone terminy moga być pomocne nie tylko przy zrozumieniu treści opisów zawartych $\mathrm{w}$ omawianych rejestrach, ale także ułatwić lekturę ustaw wymierzonych w przesadny zbytek strojów i ozdób, które posługuja się niekiedy tymi samymi terminami przy formułowaniu ubraniowych zakazów.

Głównym celem towarzyszacych edycji opracowań jest przede wszystkim przedstawienie źródła dotychczas w niewielkim stopniu zbadanego i rzadko pojawiającego się $\mathrm{w}$ literaturze przedmiotu oraz zarysowanie możliwych perspektyw badawczych - ten cel został przez autorów

terminologią użytą do opisu strojów, wzbogaconą o cząstkowe obliczenia statystyczne dot. popularności niektórych materiałów, wzorów i zdobień; zob. taż, Compter et nommer l'ètoffe à Florence au Trecento (1343), „Médiévales” 29, 1995, s. 87-104; taż, Orli, nastri e righe, passamaria e tessitura nelle vesti fiorentine, del Trecento (1343), „Archivio di storico italiano” 163, 2005, s. 133-157.

${ }^{82}$ Taż, Aspetti della moda femminile..., s. XVI.

83 Por. wyżej, przyp. 50 (dot. terminu nexus lub nodus Salomonis).

${ }^{84}$ J.F. Vaucher de la Croix, dz. cyt., s. CIII-CLII. O nazwach części garderoby w późnośredniowiecznej Toskanii zob. A. Rossi, I nomi delle vesti in Toscana durante il medioevo, „Studi di lessiconografia italiana” 11, 1991, s. 5-124. 
osiagnięty. Omówione wyżej artykuły towarzyszące wydaniu rejestrów nie zawsze sa jednak komplementarne, za to ich autorzy poświęcaja znaczną część rozważań podobnym zagadnieniom, niepotrzebnie powtarzając po wielokroć podstawowe informacje, związane np. z chronologia stanowienia praw wymierzonych w zbytek, z kontekstem politycznym czy też podstawową charakterystyką źródła. Zabrakło za to studium na temat podaży luksusowych tekstyliów (produkcja sukna luksusowego rozwinęła się we Florencji dopiero w drugiej połowie XIV w., drogie tkaniny jedwabne pochodziły w całym tym stuleciu z importu) i biżuterii, florenckiego rynku dóbr konsumpcyjnych, a także miejskiego zaplecza wytwórczego (cechy i ich interesy) ${ }^{85}$. Na usprawiedliwienie zespołu edytorskiego trzeba jednak zauważyć, że problematyka ta rzadko pojawia się w kontekście ustawodawstwa antyzbytkowego, a już szczególnie, jeśli dotyczy ono średniowiecza.

\section{Bibliografia}

\section{Źródła archiwalne}

Archivio di Stato di Firenze, Provvisioni Registri.

Archivio di Stato di Firenze, Capitoli del Comune di Firenze.

\section{Źródła opublikowane}

Prammatica sulle vesti delle donne fiorentine (Firenze 1343-1345), w: Draghi rossi e querce azzurre. Elenchi descrittivi di abiti di lusso (Firenze 1343-1345), wyd. L. Gérard-Marchant, Firenze 2013 (Memoria Scripturarum, 6; Testi latini, 4), s. 3-516.

Sacchetti F., Il Trecentonovelle, red. E. Faccioli, Torino 1979.

Statuti della Repubblica Fiorentina 1322-25, red. G. Pinto, F. Salvestrini, A. Zorzi, Firenze 1999.

Villani G., Nuova Cronica, wyd. G. Porta, Parma 1991.

\section{Opracowania}

Becker B., Florentine Popular Government (1343-1348), „Proceedings of the American Philosophical Society” 106, 1962, nr 4, s. 360-382.

${ }^{85}$ Dla późniejszego okresu zob. E. Welch, Shopping in Renaissance. Consumer Culture in Italy, 1400-1600, New Haven-London 2005. 
Becker M., Florence in Transition, t. 2: The Decline of the Commune, Baltimore-London 1967.

Biscione G., L'Ufficiale delle donne, degli ornamenti e delle vesti. Profilo istituzionale e vicende archivistiche, w: Draghi rossi e querce azzurre. Elenchi descrittivi di abiti di lusso (Firenze 1343-1345), wyd. L. Gérard-Marchant, Firenze 2013 (Memoria Scripturarum, 6; Testi latini, 4), s. LXXV-CII.

D'Ancona P., Le vesti delle donne fiorentine nel secolo XIV, Perugia 1906.

Frick C.C., Dressing Renaissance Florence. Families, Fortunes and Fine Clothing, Baltimore-London 2002.

Gérard-Marchant L., Compter et nommer l'ètoffe à Florence au Trecento (1343), „Médiévales” 29, 1995, s. 87-104.

Gérard-Marchant L., Orli, nastri e righe, passamaria e tessitura nelle vesti fiorentine, del Trecento (1343), „Archivio di storico italiano” 163, 2005, s. $133-157$.

Gérard-Marchant L., Aspetti della moda femminile a Firenze nella Prammatica del 1343, w: Draghi rossi e querce azzurre. Elenchi descrittivi di abiti di lusso (Firenze 1343-1345), wyd. L. Gérard-Marchant, Firenze 2013 (Memoria Scripturarum, 6; Testi latini, 4), s. IX-XVII.

Guimbard C., Appunti sulla legislazione suntuaria à Firenze dal 1281 al 1381, „Archivio Storico Italiano” 150, 1992, s. 57-81.

Klapisch-Zuber Ch., I freni al lusso nella Firenze del Trecento, w: Draghi rossi e querce azzurre. Elenchi descrittivi di abiti di lusso (Firenze 1343-1345), wyd. L. Gérard-Marchant, Firenze 2013 (Memoria Scripturarum, 6; Testi latini, 4), s. XVII-XXVIII.

Kizik E., Ubiory mieszczek gdańskich mieszczek $w$ końcu XVI $i$ w pierwszej połowie XVII wieku, „Rocznik Gdański” 67-68, 2007-2008 [2010], s. 17-31.

Kovesi Killerby C., Practical Problems in the Enforcement of Italian Sumptuary Law, 1200-1500, w: Crime and Disorder in Renaissance Italy, red. K. Lowe, Cambridge 1993, s. 91-120.

Manikowska H., Nadzór i represja. Władza i społeczeństwo w późnośredniowiecznej Florencji, Warszawa 1993.

Myśliwski G., Leges sumptuariae w średniowiecznym Lwowie, w: Świat średniowiecza. Studia ofiarowane Profesorowi Henrykowi Samsonowiczowi, red. A. Bartoszewicz, G. Myśliwski, J. Pysiak, P. Żmudzki, Warszawa 2007, s. 222-232.

Muzzarelli M.G., Gli inganni delle apparenze. Disciplina di vesti ed ornamenti alla fine del medioevo, Torino 1996.

Muzzarelli M.G., Belle vesti, dure leggi: „In hoc libro [...] continentur et descripte sunt omnes et singule vestes”, Bologna 2003.

Muzzarelli M.G., Reconciling the Privilege of Few with the Common Good. Sumptuary Laws in Medieval Early Modern Europe, „Journal of Medieval and Early Modern Studies" 39, 2009, 3, s. 597-617.

Owen Hughes D., Sumptuary Laws and Social Relations in Renaissance Italy, w: Disputes and settlements. Laws and Human Relations in the West, red. J. Bossy, Cambridge 1983, s. 87-88. 
Owen Hughes D., Regulating Women Fashion, w: A History of Women in the West, t. 2: Silences of Middle Ages, red. Ch. Klapisch-Zuber, Cambridge 1995, s. $136-158$.

Pastoureau M., Diabelska materia. Historia pasków i tkanin w paski, tłum. M. Ochab, Warszawa 2004.

Pomierny A., Zbytek i prestiz. Kategoria ubioru w ustawodawstwie antyzbytkowym komunalnej Florencji, w: Habitus facit hominem. Społeczne funkcje ubioru w średniowieczu i epoce nowożytnej, red. E. Wółkiewicz, M. Saczyńska, M. Pauk, Warszawa 2016, s. 141-161.

Rainey R.R., Sumptuary Legislation in Renaissance Florence, New York 1985, mps rozprawy doktorskiej, Columbia University.

Rainey R.R., Dressing Down the Dressed-Up. Reproving Feminine Attire in Renaissance Florence, w: Renaissance Society and Culture. Essays in Honour of Eugene F. Rice, red. J. Monfasani, R.G. Musto, New York 1991, s. $217-237$.

Rublack U., Dressing Up. Cultural Identity in Renaissance Europe, Oxford 2011.

Stuard S.M., Gilding the Market Luxury and Fashion in Fourteenth Century Italy, Philadelphia 2006.

Sznura F., La „Prammatica fiorentina”. Redazione e contenuto, w: Draghi rossi e querce azzurre. Elenchi descrittivi di abiti di lusso (Firenze 1343-1345), wyd. L. Gérard-Marchant, Firenze 2013 (Memoria Scripturarum, 6; Testi latini, 4), s. XXXIX-LXXIV.

Taddei I., Fanciulli senza porpore. Le fogge della moda maschile e la condanna del lusso a Firenze fra XIV e XV secolo, w: Uomini, Paessaggi. Storie. Studi di storia medievale per Giovanni Cherubini, t. 2, red. D. Balestraćci i in., Firenze 2012, s. 1071-1088.

Vaucher de la Croix J.F., Le parole nell'armadio: lessico della moda nella Prammatica sulle vesti delle donne fiorentine, w: Draghi rossi e querce azzurre. Elenchi descrittivi di abiti di lusso (Firenze 1343-1345), wyd. L. Gérard-Marchant, Firenze 2013 (Memoria Scripturarum, 6; Testi latini, 4), s. CIII-CLII.

Veblen Th., Teoria klasy próżniaczej, tłum. J. Frentzel-Zagórska, Warszawa 2008.

Anna Pomierny-Wąsińska

Luxury registered. On Florentine registers of expensive clothes and accessories of $1343-1345$

(Summary)

The article discusses registers of luxury gods issued in Florence in 1343-1345 . The main purpose of the text is to characterise the uniqueness of this source and its importance for research into the history of luxury in late medieval 
cities, and to outline research perspectives provided by this type of source. First, the main features of the registers are presented, together with a description of historical circumstances of their origin and the process of their emergence. Next, their importance for social research (i.a. prosopography) and for broadly understood studies on material culture in late medieval towns and cities is discussed. The last part presents the publications written with the use of this source on the subject of luxury culture of Florence, and - more broadly - of Italy; this part contains also critical remarks on the literature on the subject with an analysis of the most recent studies in this area, which are the texts accompanying the source edition.

Anna Pomierny-Wąsińska - absolwentka Instytutu Historycznego Uniwersytetu Warszawskiego, obecnie doktorantka w Instytucie Historii im. Tadeusza Manteuffla PAN. Specjalizuje się w badaniach nad miastami włoskimi w późnym średniowieczu, kończy pracę doktorską na temat kategorii miary przestrzennej i roli mierniczych miejskich w późnośredniowiecznej Florencji.

Anna Pomierny-Wąsińska - a graduate from the Institute of History, University of Warsaw, at present a PhD student at Tadeusz Manteuffel Institute of History, Polish Academy of Sciences; she specialises in research on Italians cities in the late Middle Ages; she finishes her $\mathrm{PhD}$ thesis on the category of spatial measurement and role of municipal land surveyors in late medieval Florence.

E-mail: apomierny@gmail.com. 